\title{
Seasonal Changes of House Dust Mite Population in Bitlis and Muş Provinces of Turkey
}

\author{
Türkiye’nin Doğu Kesimlerinde (Bitlis, Muş) Ev Tozu Akar Populasyonundaki Mevsimsel
}

Değişikler

\author{
Medeni Aykut ${ }^{1}$, Ömer Köksal Erman², Salih Doğan³ \\ 'Dicle University, Graduate School of Natural and Applied Sciences, Diyarbakır, Türkiye \\ 2Department of Biology, Atatürk University, Science Faculty, Erzurum, Türkiye \\ ${ }^{3}$ Department of Biology, Erzincan University, Arts\&Sciences Faculty, Erzincan, Türkiye
}

\begin{abstract}
Objective: This study was conducted to determine the dust mite fauna of houses in Bitlis and Muş provinces, the monthly value of mite numbers/g dust, as well as the impact of temperature, humidity and altitude on their numbers.

Methods: Dust samples were collected monthly from May 2010 to April 2011 from six houses belonging to three settlements; two of the houses were located in Bitlis, while another four were in Muş province.

Results: All 72 examined dust samples were found to be positive with regard to mites. The number of mites found in $1 \mathrm{~g}$ dust varied from 25 to 2,740. Overall, 1,167 house dust mites belonging to the orders Astigmata, Mesostigmata and Prostigmata were isolated. Dermatophagoides pteronyssinus was the predominant mite (83.2\%), followed by Lepidoglyphus destructor (6.3\%), Acarus siro (2.7\%) and Tyrophagus putrescentiae (1.9\%). The mite numbers were higher in the warmer months of the year.

Conclusion: The dominant mite in the Bitlis and Muş provinces is Dermatophagoides pteronyssinus, and the highest mite numbers were found in months in which the outside humidity was low. (Turkiye Parazitol Derg 2013; 37: 113-7)
\end{abstract}

Key Words: Dermatophagoides, Turkey, Muş, Bitlis, seasonality

Received: 23.11.2012

Accepted: 04.03 .2013

\section{ÖZET}

Amaç: Bu çalışma Bitlis ve Muş illerinin ev tozu akar faunasını, akar sayısı / 1 g ev tozu değerinin aylık dağılımını belirlemek ve sıcaklık, nem, rakım gibi faktörlerin akar sayısı üzerindeki etkilerini araştırmak amacıyla yapılmıştır.

Yöntemler: Bu amaçla; Muş ve Bitlis illerine ait 3 yerleşim yerinden ikişer evden olmak üzere toplam 6 evden; Mayıs-2010 ile Nisan-2011 tarihleri arasında her ay toz örnekleri toplandı.

Bulgular: Çalışma kapsamında toplanan 72 toz örneğinin hepsi akar bakımından pozitif bulundu. Bir gram tozda bulunan akar sayısı; 252740 arasında değişiklik göstermiştir. Çalışmamızda; Astigmata, Mesostigmata ve Prostigmata takımlarına ait 1167 ev tozu akarı izole edildi. Çalışma bölgesinde Dermatophagoides pteronyssinus en sık görülen $(\% 83,2)$ ev tozu akarı olarak kaydedildi. Bunu sırasıyla Lepidoglyphus destructor $(\% 6,26)$, Acarus siro $(\% 2,74)$ ve Tyrophagus putrescentiae $(\% 1,89)$ takip etmiştir.

Sonuç: Dış ortam nem oranının düşük olduğu aylarda yüksek akar sayısı/g toz değerleri elde edildi. (Turkiye Parazitol Derg 2013; 37: 113-7)

Anahtar Sözcükler: Dermatophagoides, Türkiye, Muş, Bitlis, mevsimsellik

Geliş Tarihi: 23.11.2012

Kabul Tarihi: 04.03 .2013

This study was presented at the $6^{\text {th }}$ International Symposium on Ecology and Environmental Problems, 17-20 November 2011, Antalya, Turkey. 17-20 Kasım 2011 tarihlerinde Antalya'da düzenlenen VI. Uluslararası Ekoloji ve Çevre Sorunları Sempozyumu'nda sunulmuştur.

Address for Correspondence / Yazışma Adresi: Dr. Medeni Aykut, Dicle University, Graduate School of Natural and Applied Sciences, Diyarbakır, Türkiye Phone: +90 5052726788 E-mail: medeniaykut@hotmail.com doi:10.5152/tpd.2013.26 


\section{INTRODUCTION}

House dust contains many allergens; the most significant ones arriving from the house dust mites (HDM). In general, the term "house dust mite" refers to mites belonging to Pyroglyphidae family from the order Astigmata, which regularly live within the dust of houses (1). Dermatophagoides pteronyssinus, Dermatophagoides farinae and Euroglyphus maynei are the most frequently encountered mites in dust (2-4).

HDM primarily live in hot and humid environments $(75-80 \%$ relative humidity 9 and $25-30^{\circ} \mathrm{C}$ ). Their development from egg to adult stage under laboratory conditions lasts approximately 3-4 weeks. Adults live for 4-6 weeks on average (1). They feed on skin scales of human and animal origin as well as on microorganisms growing on it (1-3).

The main biotopes of HDM are carpets, pillows, blankets, mattresses and sofas. Their sizes vary between 100-350 $\mu \mathrm{m}$, and accordingly, they are difficult to visualise with the naked eye (1-3). The secretions/excretions of HDM are potent allergens and cause allergic reactions in predisposed individuals such as atopic dermatitis, asthma and atopic rhinitis. HDM are known to be one of the foremost causes of asthma in children $(1,2)$.

In Turkey, Budak (1) found that the higher the location of a settlement the lower the number of HDM. The percentages of houses in which HDM were found varied between 16 and $87 \%(2,5-11)$.

In Turkey, the occurrence of house dust mites in dwellings and their seasonal dynamics is poorly known. The aim of this study was to investigate the seasonal dynamics of mite populations in dust from dwellings and the relationship between mite density and humidity, temperature and altitude.

\section{METHODS}

Selection of Study Region and Houses: Three villages were selected for this study: Tatvan in the district of Bitlis $11,430 \mathrm{~m}$ altitude), Hasköy (1,300 m altitude) and Dağdibi (1,600 m altitude) in the district of Muş. The houses had the following characteristics: single family stone houses (10-15 years old), heated by a wood stove, where 5-7 people were living and a carpet was present in the living room.

Collection of Dust Samples: Dust samples were collected with a vacuum cleaner (Jet Line Efor JT-01 1600 Watt) from carpets in living rooms, monthly for 12 months between May 2010 and April 2011. A $1 \mathrm{~m}^{2}$ surface was vacuumed for $2 \mathrm{~min}$. Each carpet was divided into six sections and a dust sample was collected from a different section of the carpet each month. Accordingly, each surface was vacuumed twice with an interval of 6 months. Overall, 72 dust samples were collected from six houses. The average monthly temperature and humidity values of sampled settlements were provided from the Regional Directorate of Erzurum Meteorological Service.

Extraction of dust mites: Dust samples were sieved separately in a mechanical sieve shaker, using a stack of sieves with mesh sizes of 1 and $0.5 \mathrm{~mm}$ in order to remove the large particles; $1 \mathrm{~g}$ of the fine dust was examined. The dust samples were heated close to boiling in $25 \mathrm{~mL} 90 \%$ lactic acid. After heating, small samples of the liquid were transferred to a Petri dish and examined under a stereomicroscope for the presence of mites, according to the described methods $(1,12)$.

Identification: Mites were transferred with the help of a fine bristle to Hoyer's medium and permanent preparations were prepared. The identification of HDM was made according to the published keys $(13,14)$.

\section{Statistical Analyses}

To explore the relationship between mite numbers and humidity, temperature and altitude, a simple product-moment correlation analysis was conducted. All data were analysed using SPSS 15.0 for windows.

\section{RESULTS}

All examined dusts samples were positive for mites. The number of mites/1 $\mathrm{g}$ dust varied between 25 and 2,470. The maximum number of mites/gram dust $(2,470)$ was observed from house 1 in Dağdibi village in September 2010 and the minimum value (25) was seen from house 1 in Hasköy.

An increase in the number of mites was observed between June and September in Hasköy when the outside monthly average temperature was the highest (Figure 1). A similar situation was also seen in Dagdibi, where the mite numbers were high in November (Figure 2), while in Tatvan the mite numbers were high during the whole year in one house and lowest in AugustOctober in the second house (Figure 3). The highest mite numbers were found in months in which the outside humidity was low.

Overall, 1,167 mites belonging to Astigmata, Mesostigmata and Prostigmata orders were isolated. From these 1,136 (97.34\%) belonged to the order Astigmata, 17 (1.5\%) to the order Prostigmata order and $14(1.2 \%)$ to Mesostigmata. Dermatophagoides pteronyssinus (Figure 4) was the most prevalent mite (83.2\%), followed by Lepidoglyphus destructor (Figure 5) (6.3\%), Acarus siro (Figure 6) (2.7\%), Tyrophagus putrescentiae (Figure 7) (1.9\%), Euroglyphus maynei (1.3\%), Glycyphagus domesticus (1.3\%), Chortoglyphus arcuatus (0.3\%), Dermatophagoides evansi (0.2\%) and Gohieria fusca (0.2\%) (Table 1).

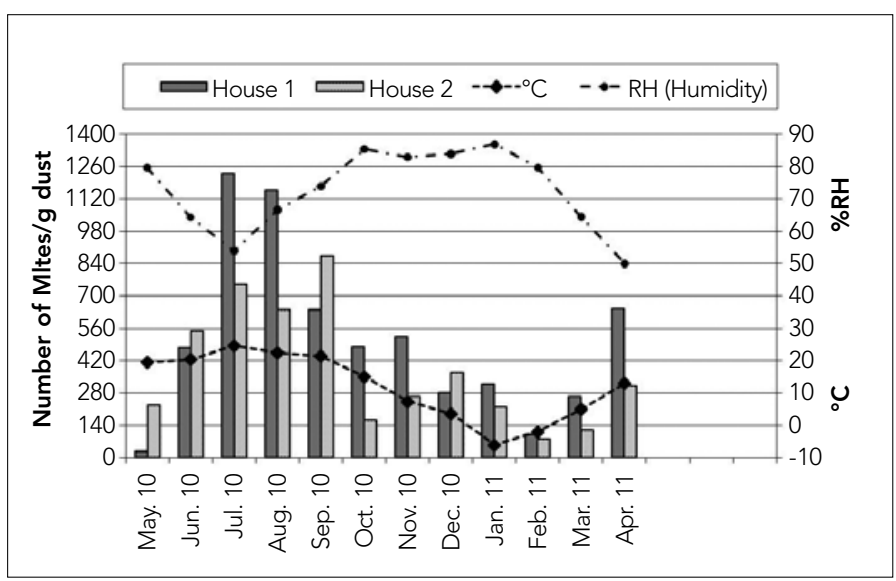

Figure 1. Monthly distribution of mite numbers per $g$ dust in two houses of Hasköy 


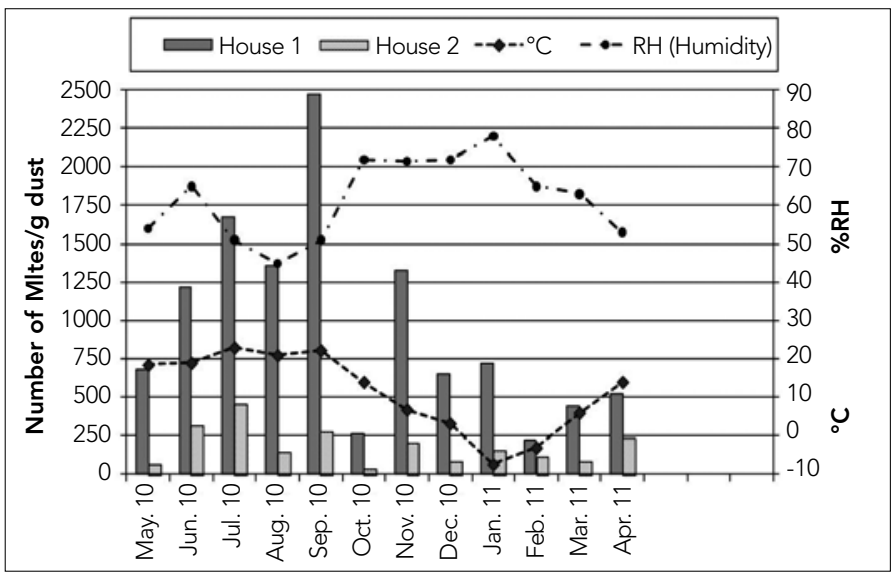

Figure 2. Monthly distribution of mite numbers per $g$ dust in two houses in Dağdibi

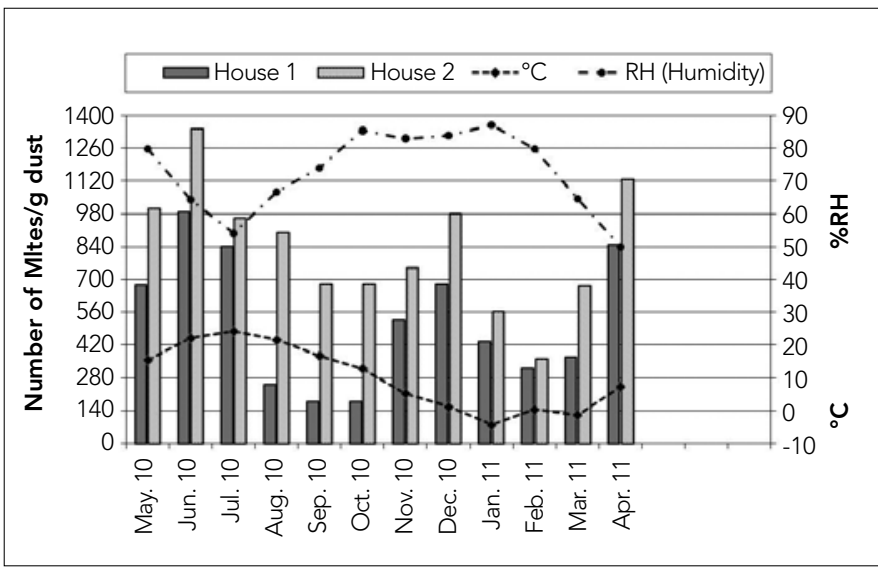

Figure 3. Monthly distribution of mite numbers per $g$ dust in two houses in Tatvan

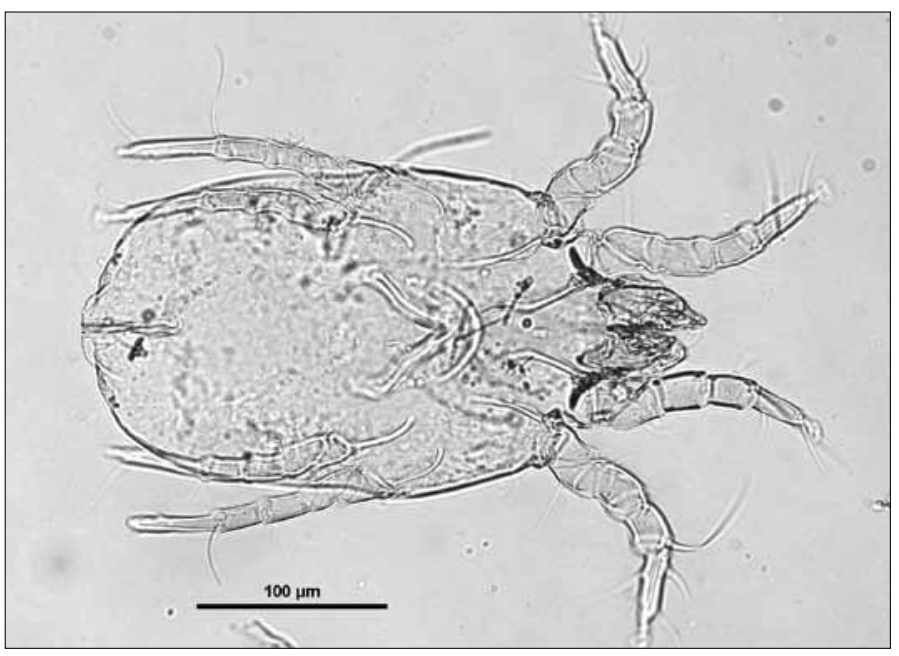

Figure 4. Dermatophagoides pteronyssinus (Female)

There was a significant correlation between temperature and mite density $(P<0.05)$ in both houses of Hasköy and house 1 of Tatvan, however no such correlation could be found with the remaining houses. In addition, no statistical correlation between mite density and humidity or altitude could be found.

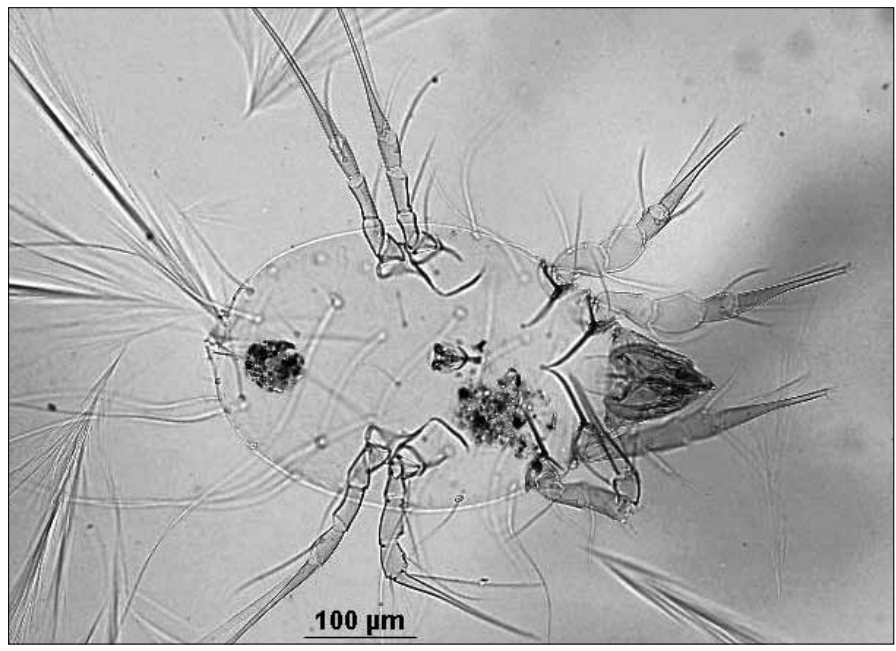

Figure 5. Lepidoglyphus destructor (Male)

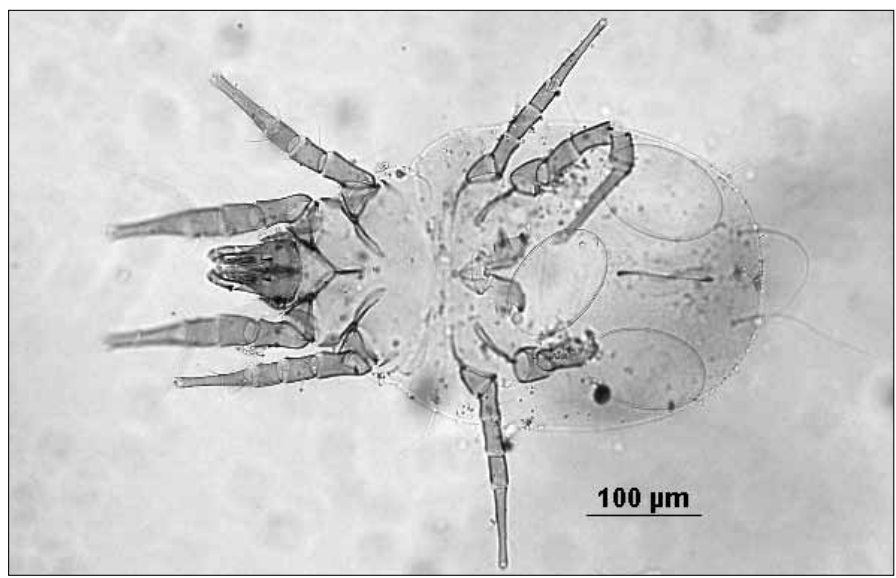

Figure 6. Acarus siro (Female)

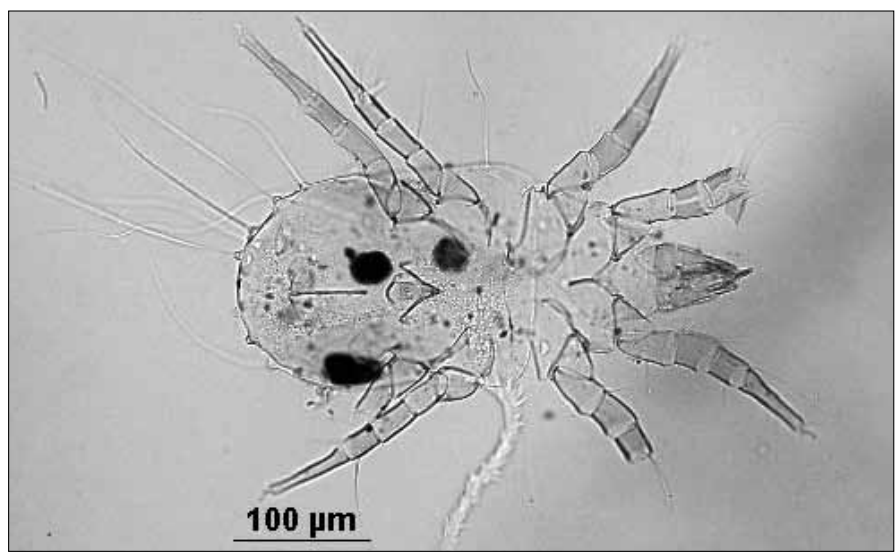

Figure 7. Tyrophagus putrescentiae (Male) DISCUSSION

In the present study, Dermatophagoides pteronyssinus (83.2\%) was the dominant mite in house dust. This is in accordance with studies performed in other countries, e.g., Scotland (15), China (16), Israel (4), Taiwan (17), Peru (18), India (19) Iran (20), Lithuania (21), Malaysia (22) and Poland (23), as well as in different studies conducted in Turkey, e.g., in Bursa (24), Afyon, Isparta, Uşak, Kütahya and Denizli (25), Konya (26), Malatya (9) and Muş (11). 
Table 1. Total number and prevalence of house dust mites isolated from six houses during a year

\begin{tabular}{|c|c|c|}
\hline & Number & $\%$ \\
\hline ASTIGMATA & 1.136 & 97.3 \\
\hline \multicolumn{3}{|l|}{ Pyroglyphidae } \\
\hline Dermatophagoides pteronyssinus & 971 & 83.2 \\
\hline Dermatophagoides evansi & 2 & 0.2 \\
\hline Euroglyphus maynei & 15 & 1.3 \\
\hline \multicolumn{3}{|l|}{ Glycyphagidae } \\
\hline Lepidoglyphus destructor & 73 & 6.3 \\
\hline Glycyphagus domesticus & 15 & 1.3 \\
\hline Goiheria fusca & 2 & 0.2 \\
\hline \multicolumn{3}{|l|}{ Chortoglyphidae } \\
\hline Chortoglyphus arcuatus & 4 & 0.3 \\
\hline \multicolumn{3}{|l|}{ Acaridae } \\
\hline Acarus siro & 32 & 2.7 \\
\hline Tyrophagus putrescentiae & 22 & 1.9 \\
\hline \multicolumn{3}{|l|}{ PROSTIGMATA } \\
\hline Cheyletidae & 17 & 1.5 \\
\hline MESOSTIGMATA & 14 & 1.2 \\
\hline Total & 1.167 & 100 \\
\hline
\end{tabular}

Akdemir and Gürdal (27) examined the monthly distribution of HDM in Kütahya and found that the mite number was highest during June to September, as was the case in this study. In the present study, the number of mites/gram dust varied between 25 and 2,740 and were considerably higher than those obtained by Akdemir and Gürdal (27).

The higher number of mites observed in the hotter months of the year is also in accordance with other studies conducted in Turkey and abroad $(2,4,6,15)$.

\section{CONCLUSION}

In the present study, the HDM numbers were higher when the external humidity was low. However, HDM thrive better under humid conditions. Although the environmental humidity was higher in the colder months of the year due to the rain and snow, the humidity inside the houses was most probably much lower, due to heating with a stove. Therefore, it might be important to measure the temperatures and humidity in specific houses when the dust samples are collected.

\section{Conflict of Interest}

No conflict of interest was declared by the authors.

Peer-review: Externally peer-reviewed.

\section{Author Contributions}

Concept - M.A., Ö.K.E., S.D.; Design - M.A., Ö.K.E., S.D.; Supervision - Ö.K.E., S.D.; Funding - M.A.; Materials - M.A.; Data Collection and/or Processing - M.A.; Analysis and/or Interpretation - M.A., Ö.K.E., S.D.; Literature Review - M.A.;
Writing - M.A., Ö.K.E., S.D.; Critical Review - M.A., Ö.K.E., S.D.; Other - M.A., Ö.K.E., S.D.

\section{Acknowledgement}

This study was supported by a Research Fund of the Ataturk University (BAP-168 2009/235) and was part of the PhD thesis supervised by O. K. Erman and S. Doğan.

We are grateful to Dr Kosta Y. Mumcuoglu; The Kuvin Center for the Study of Infectious and Tropical Diseases, Faculty of Medicine, Hebrew University, Jerusalem, Israel, for his help throughout the study.

\section{Çıkar Çatışması}

Yazarlar herhangi bir çıkar çatışması bildirmemişlerdir.

Hakem değerlendirmesi: Dış bağımsız.

\section{Yazar Katkıları}

Fikir - M.A., Ö.K.E., S.D.; Tasarım - M.A., Ö.K.E., S.D.; Denetleme Ö.K.E., S.D.; Kaynaklar - M.A.; Malzemeler - M.A.; Veri toplanması ve/veya işlemesi - M.A.; Analiz ve/veya yorum - M.A., Ö.K.E., S.D.; Literatür taraması - M.A.; Yazıyı yazan - M.A., Ö.K.E., S.D.; Eleştirel İnceleme - Ö.K.E., S.D.; Diğer - M.A., Ö.K.E., S.D.

\section{Teşekkür}

Bu çalışma Atatürk Üniversitesi Bilimsel Araştırma Projeleri Tarafından desteklenmiştir (BAP 2009/235). Ö. K. Erman ve S. Doğan'ın gözetiminde hazırlanan tezin bir parçasıdır.

Çalışmaya katkılarından dolayı, Prof. Dr. Kosta Y. Mumcuoğlu'na (The Kuvin Center for the Study of Infectious and Tropical Diseases, Faculty of Medicine, Hebrew University, Jerusalem, Israel) teşekkür ederiz.

\section{REFERENCES}

1. Colloff MJ. Dust mites. 2009; CSIRO Publishing, Collingwood, Australia. [CrossRef]

2. Budak S. Ege Bölgesi'nde tıbbi önemi olan Dermatophagoides pteronyssinus'un yayılışı. T Parazitol Derg 1984; 8: 145-52.

3. Özçelik S. Artropod Hastalıkları ve Vektörler. 1997; Türkiye Parazitoloji Derneği Yayınları, İzmir, Turkey.

4. Mumcuoglu KY, Gat Z, Horowitz T, Miller J, Bar-Tana R, Ben-Zvi A, et al. Abundance of house dust mites in relation to climate in contrasting agricultural settlements in Israel. Med Vet Entomol 1999; 13: 252-8. [CrossRef]

5. Budak S. Ege bölgesi'nde ev tozlarındaki akar faunası. T Parazitol Derg 1988; 12: 355-61.

6. Kapaklığlu AF, Emekçi M, Ferizli AG, Mısırlıgil Z. House dust mite fauna in Turkey. J Investig Allergol Clin Immunol 1997; 7: 578-82.

7. Güngör Ç, IşıK K, Cicioğlu B, Altıntaş K. Isparta'da halı atölyelerinde ev tozu akarlarının yaygınlığı ve dokumacılık yapan kadınlarda allerjik şikayetlerin akarlarla ilişkisi. T Parazitol Derg 1999; 23: 32-4.

8. Aygan Ç, Özçelik S. Sivas yöresinde ev tozu akarlarının yaygınlığı ve atopik allerjideki rolü. T Parazitol Derg 2002; 26: 186-91.

9. Atambay M, Aycan MÖ, Daldal N. Malatya'da ev tozu akar faunası. T Parazitol Derg 2006; 30: 205-8.

10. Doğan N, Aycan MÖ, Miman Ö, Atambay M, Daldal N. Eskişehir'de ev tozu akarı görülme durumu. T Parazitol Derg 2008; 32: 139-41.

11. Aykut M, Yılmaz H. Muş ili Hasköy İlçesinde ev tozu akarlarının yayılışı. T Parazitol Derg 2010; 34: 160-3. [CrossRef]

12. Arlian LG. Water balance and humidity requirements of house dust mites. Exp Appl Acarol 1992; 16: 15-35. [CrossRef] 
13. Spieksma FT. Identification of house-dust mites. Aerobiologia 1990; 6: 187-92. [CrossRef]

14. Colloff MJ, Spieksma FT. Pictorial keys for the identification of domestic mites. Clin Exp Allergy 1992; 22: 823-30. [CrossRef]

15. Colloff MJ. Mites from housedust in Glasgow. Med Vet Entomol 1987; 1: 163-8. [CrossRef]

16. Wen CLT. Faunal survey and seasonal prevalence of house dust mites in the urban area of Shangai. Acta Ecol Sin 1989; 3: 102-8.

17. Sun HL, Lue KH. Household distribution of house dust mite in central Taiwan. Chinese J Microbiol 2000; 33: 233-6.

18. Adriel-Gudiel H, Jorge-Gudiel H, Lissié Tincopa A, Dutau G, Rancé F. Étude des sensibilisations aux aéroallergènes chez les enfants asthmatiques âgés de plus de trois ans et habitant dans la zone Nord de Lima (Pérou). Rev Fr Allergol 2009; 49: 403-9. [CrossRef]

19. Podder S, Gupta KS, Saha GK. Seasonal prevalence of allergenic mites in house dust of Kolkata Metropolis, India. Aerobiologia 2009; 25: 39-47. [CrossRef]

20. Soltani A, Azizi K, Saleh V, Dabaghmanesh T. The fauna and distribution of house dust mites in residential homes of Bandar Abbas District, Southern Iran. Exp Appl Acarol 2011; 54: 269-76. [CrossRef]
21. Dautartiene A. Seasonal changes in house dust mites. Ekologija 2009; 2: 3-7.

22. Mariana A, Ho TM, Sofian-Azirum M, Wong AL. House dust mite fauna in the Klang Valley, Malaysia. Southeast Asian J Trop Med Public Health 2000; 31: 712-21.

23. Solarz K. Seasonal dynamics of house dust mite populations in bed/ mattress dust from two dwellings in Sosnowiec (Upper Silesia, Poland): An Attempt to assess exposure. Ann Agr Env Med 1997; 4: 253-61.

24. Güleğen E, Girişgin $O$, Kütükoğlu F, Girişgin AO, Coşkun ŞZ. Bursa evlerinde bulunan ev tozu akar türleri. T Parazitol Derg 2005; 29: 185-240.

25. Ciftci IH, Cetinkaya Z, Atambay M, Kiyildi N, Aycan OM, Daldal N. House dust mite fauna in western Anatolia, Turkey. Korean J Parasitol 2006; 44: 259-64. [CrossRef]

26. Aldemir SO, Baykan M 2004. Su hazneli ve toz torbalı elektrik süpürgeleri ile toplanan toz örneklerinde ev tozu akarlarının (Dermatophagoides pteronyssinus) araştırılması. Kafkas Univ Vet Fak 2004; 10: 171-3.

27. Akdemir C, Gürdal H. Kütahya'da ev tozu akarları. Dumlupınar Üniv Fen Bil Enst Derg 2004; 7: 27-40. 